\title{
Duration of the Pre-Settlement Period of the Mangrove Crab Ucides cordatus (Decapoda: Ocypodidae) Under Laboratory Conditions
}

\author{
Robson Ventura*1, Ubiratã de Assis Teixeira da Silva, Gilmar Perbiche-Neves, Antonio \\ Ostrensky, Walter Antonio Pereira Boeger and Marcio Roberto Pie \\ ${ }^{I}$ Grupo Integrado de Aqüicultura e Estudos Ambientais; Universidade Federal do Paraná; Rua dos Funcionários, \\ 1540; robson.ventura@gmail.com; 80035-050; Curitiba - PR - Brasil
}

\begin{abstract}
The goal of the present study was to determine the most appropriate time to release the immatures of Ucides cordatus (Linnaeus) produced in the laboratory into the natural environments. Specifically, the time when the megalopae sought the mangrove sediment to excavate the burrows was determined, as well as the time necessary for their metamorphosis into the first juvenile stage. Results indicated that the megalopae of $\mathrm{U}$. cordatus reared in the laboratory took three to ten days (median $=6)$ after their molt to excavated burrows in the sediment. The average time for the megalopae to molt into juveniles was 12.6 days $(S D=2.3)$.
\end{abstract}

Key words: Ucides cordatus, restocking, larval rearing, settlement, megalopae, juvenile

\section{INTRODUCTION}

The mangrove crab Ucides cordatus (Linnaeus) is among the most important components of the mangrove ecosystems of the Western Atlantic, both as an essential link in local food chains and in processing of the plant material (Wolff et al., 2000). In addition, poor families of many coastal human populations in Brazil depend on the mangrove crab as a fishery resource (Diegues, 1987; Auto, 2001). Recent years have witnessed severe reductions in the stocks of the mangrove crab, not only due to habitat destruction and overfishing, but also following the spread of an emerging infectious infirmity (Lethargic Crab Disease, Boeger et al., 2005), raising the concerns with respect to the long-term sustainability of this fishery.
An important tool for the management of depauperate populations of the mangrove crab is the mass production of the immature forms and their subsequent release into natural habitats. As in many estuarine decapods, $U$. cordatus displays larval exportation as its dispersal strategy, with larvae being transported from their parental environment into coastal regions and later returning to the estuaries (Santarosa-Freire, 1998). In the case of $U$. cordatus, this process takes three to four weeks, when they reach the phase of megalopa (Diele, 2000). This entire process might be carried out in the laboratory, where larvae mature into a developmental stage that is suitable to be released into mangrove areas (megalopae or juveniles).

\footnotetext{
${ }^{*}$ Author for correspondence
} 
The timing for the release of the immature forms into the natural environment is crucial for the success of restocking efforts. Premature releases would include larvae still displaying planktonic behavior, exposing them to greater predation risk (Johns and Mann, 1987; Dittel et al., 1996; Moksnes et al., 1997, 1998) as well as reducing the effectiveness of the restocking due to the transport of larvae away from the focal areas. Excessively late releases, on the other hand, entail extensive losses through cannibalism within larviculture tanks (Quinitio and Parada-Estepa 1999), as well as increased rearing costs. Moreover, excessive domestication reduces the adaptability of larvae to the natural environment (Tsukamoto et al., 1999).

The goal of the present study was to determine the most appropriate time to carry out the release of the immatures produced in the laboratory into natural environments. Specifically, the moment in which the megalopae sought the mangrove sediment to excavate a burrow, as well as the time necessary for their metamorphosis into the first juvenile stage, was assessed.

\section{MATERIALS AND METHODS}

The larvae of Ucides cordatus used in this study were obtained from the ovigerous females collected from the mangroves in the municipality of Antonina, State of Paraná, Southern Brazil $\left(25^{\circ}\right.$ 25' $08^{\prime \prime} \mathrm{S}$ and $\left.48^{\circ} 42^{\prime} 33^{\prime \prime} \mathrm{W}\right)$. Females were brought to the laboratory, where they were kept under the controlled environmental conditions (26 $\mathrm{C}, \mathrm{pH} 8$, salinity 26) in 1,000L plastic tanks filled with the saltwater until the eclosion of the larvae, which occurred without any artificial stimulus. The larvae were reared in the mass larviculture tanks for 25 days in the laboratory until they molted into the megalopa phase. Microalgae (Chaetoceros sp.) and rotifers (Brachionus plicatilis) were provided as food during the first stages, being complemented, from the zoea $\mathrm{V}$ stage onward, with Artemia sp. nauplii.
Sixty larvae were individually transferred to small vials containing $250 \mathrm{~mL}$ of saltwater (salinity 25 ) on the same day that the larvae molted into the megalopae. These vials were kept in an environmental chamber under the controlled temperature $\left(26^{\circ} \mathrm{C}\right)$ and photoperiod $(15: 9 \mathrm{LD})$. The larvae were fed Artemia sp. at a concentration of 6 nauplii. $\mathrm{mL}^{-1}$. The water of these vials was replaced daily. During the first two days, after the individualization of the megalopae, the vials contained only water and food in the solution. After that, approximately $14 \mathrm{~cm}^{3}$ of mangrove soil, previously screened with a $0.5 \mathrm{~mm}$ mesh size steel net, was hand shaped like a sphere and placed at the bottom of the vials, in order to provide a substrate for the megalopae to excavate. This shape was chosen to facilitate water replacement in the experimental vials and visualization of the burrows. The mangrove soil was collected from the Guaratuba Bay, state of Paraná, Southern

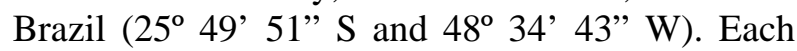
vial was censused daily for 20 days to record the time for the megalopae to excavate the burrow and the time for them to molt into the first juvenile stage.

\section{RESULTS}

Larval survival by the end of the experiment was $76.6 \%$. All the studied megalopae excavated at least one burrow prior to molting into juveniles. The median time for the megalopae to excavate their first burrow in the sediment was six days after their last molt (range 3-10 days, $\mathrm{N}=60$ individuals). Some individuals excavated up to three burrows before molting into juveniles. The average time for megalopae to molt into juveniles was 12.6 days $(\mathrm{SD}=2.3$, Fig. 1). Interestingly, once metamorphosis was complete, no juvenile was observed swimming in the water column. Rather, their moved by walking on the mud substrate. 

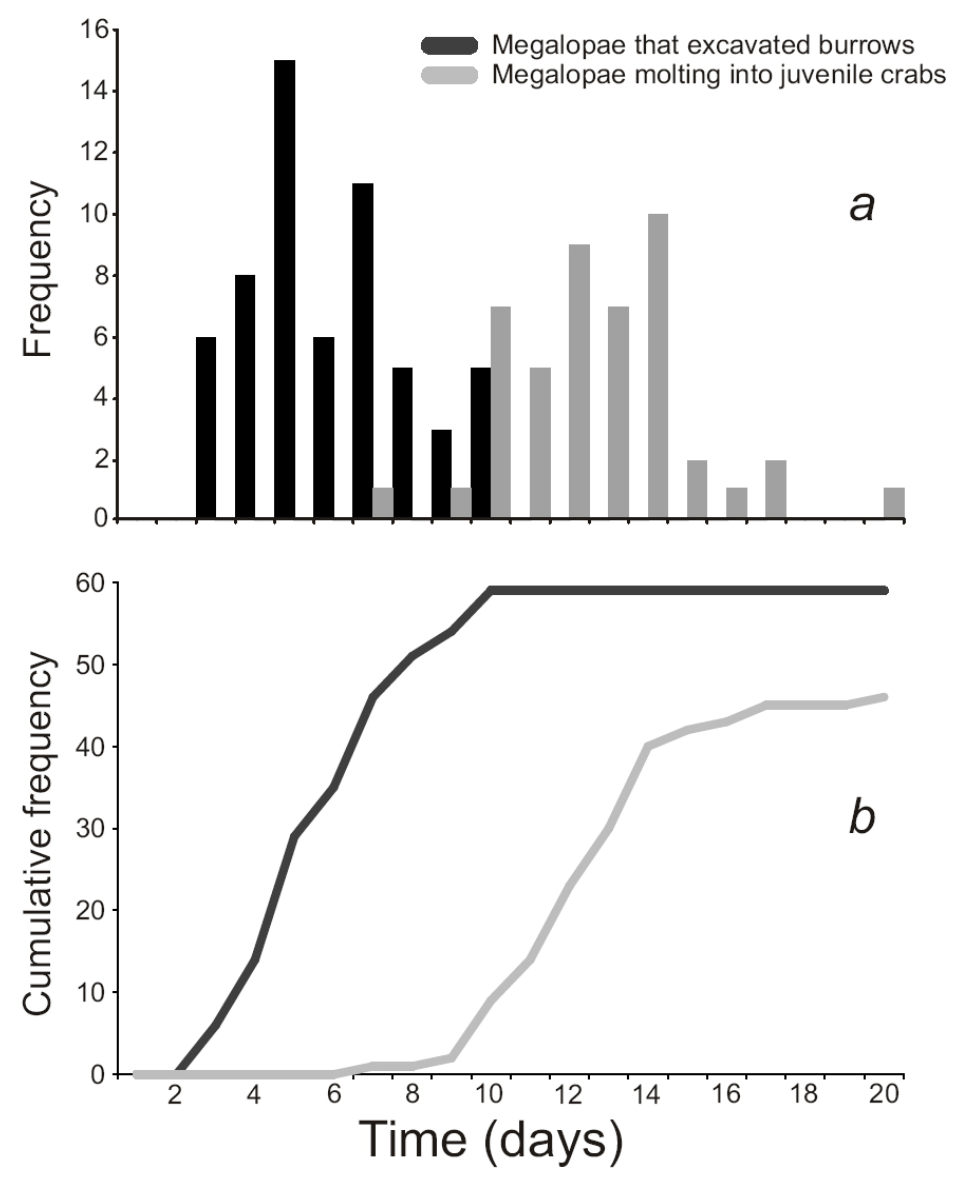

Figure 1 - Temporal variation in the number of megalopae excavating a burrow and molting into juvenile crabs over the duration of the experiment. a. Frequency distribution; b. Cumulative distribution.

\section{DISCUSSION}

The success in the use of immature crabs reared in the laboratory for restocking purposes depends strongly on their age at the time of release in the nature, as observed for Callinectes sapidus (Rathbun) and Portunus trituberculatus (Miers) (Secor, 2002). Predation tests have shown that fish, other crab species, and even more developed conspecifics might exert considerable predation pressure on the juveniles of $P$. trituberculatus cultured in the laboratory and released as the juveniles of stages I to III (Ariyama, 2000). The juveniles of this species still swam in the water column, a factor that might severely increase their predation risk (Ariyama, 2000). For that reason, since 1991, larval releases of this species have only been carried out when juveniles reached stages 4 or 5 (Secor, 2002).
The results obtained in the present study indicated that the first juvenile stage of $U$. cordatus was already benthic, being unable to swim. Therefore, the release of the juveniles of $U$. cordatus could probably be done in its first developmental stage. In addition, this study indicated that the application of the restocking technology previously developed for the portunids such as $P$. trituberculatus and $C$. sapidus could not be easily extrapolated to ocypodids such as $U$. cordatus. The basis for such difference seemed to be related to the morphological differences between these two crab families, such as the paddle-shaped pereiopods of portunids that allowed them to swim, a trait that is absent in ocypodids.

The results showed that megalopae of $U$. cordatus, reared in the laboratory, took three to ten days (median $=6$ ) after their molt to excavate burrows in the sediment. Such burrows are commonly cited as an important factor in decreasing predation rates of 
post-larvae of other aquatic organisms, such as the lobster Homarus americanus (Milne Edwards) (Barshaw and Lavalli, 1988), as well as other crab species (Heck and Hambrook, 1991; Olmi and Lipcius, 1991, Fernandez et al., 1993; Dittel et al., 1996; Moksnes et al., 1997; Hemmi, 2005; Chan et al., 2006; Zeil and Hemmi, 2006), including U. cordatus (Branco, 1993). Megalopae of $C$. sapidus are not known to excavate burrows in the sediment and therefore they usually experience high predation pressure by fish, shrimp, and even conspecifics of older cohorts, at this point of their ontogeny (Olmi and Lipicius, 1991; Moksnes et al., 1997). Thus, the present results suggested that the release of the megalopae on the sixth day from their molt might increase the survivorship of these larvae under natural conditions.

The duration of the megalopal stage in $U$. cordatus has been reported by Rodrigues and Hebling (1989) to last from 55 to 61 days if the megalopae originated from Zoeae $\mathrm{V}$, and from 43 to 69 days, if originated from Zoeae VI. These periods were considerably longer than the duration of the megalopa stage in the present study, which averaged 12.6 days. The main methodological difference between the present study and that of Rodrigues and Hebling (1989) was the presence of the mangrove sediment within the experimental container. The physicochemical characteristics of the substrates might strongly modulate the decapod metamorphosis, such as temperature (Jamieson and Phillips, 1993; McMillan et al., 1995; Anger et al., 2004), salinity (Islam et al., 2005), and conspecific chemical cues (Harvey, 1996; O'Connor and Judge, 1997; Gebauer et al., 1998; Rodríguez and Epifanio, 2000; Gebauer et al., 2002). Future studies, addressing specifically this issue, could provide important information to accelerate the larval development of $U$. cordatus and to optimize their larviculture.

\section{ACKNOWLEDGMENTS}

We thank the Government of the State of Paraná (Unidade Gestora do Fundo Paraná) and FUNPAR for funding this study.

\section{RESUMO}

O estágio de desenvolvimento em que se encontram as formas jovens de caranguejo produzidas em laboratório, no momento da sua liberação para o ambiente, é um fator chave para o sucesso dos trabalhos de repovoamento. O presente trabalho teve como objetivo determinar a idade mais adequada das formas jovens de $U$. cordatus, produzidas em laboratório, para sua liberação no ambiente natural. Especificamente, o momento em que as megalopas procuram o sedimento de mangue para escavar tocas foi determinado, assim como o tempo que demoram até realizarem a metamorfose para o primeiro estágio juvenil. O experimento indicou que as megalopas de $U$. cordatus produzidas em laboratório levam de 3 a 10 dias (mediana $=6$ ) após a metamorfose até escavarem tocas no sedimento. O tempo médio que as megalopas levaram até realizar a metamorfose para o primeiro estágio juvenil foi de 12,6 dias (desvio padrão $=2,33$ ).

\section{REFERENCES}

Anger, K., Lovrich, G., Thatje, S. and Calcagno, J. (2004) Larval and early juvenile development of Lithodes santolla (Molina, 1782) (Decapoda: Anomura: Lithodidae) reared at different temperatures in the laboratory. Journal of Experimental Marine Biology and Ecology 306, 217-230.

Auto, P.C.C. (2000) Projeto Manguezal. In-Relatório da Reunião Técnica sobre o Estado da Arte da Pesquisa e Ordenamento da Cata do Caranguejo-uçá no Nordeste do Brasil. IBAMA. Tamandaré, Pernambuco, Brazil. pp. 34-36.

Aryama, H. (2000) Studies on Ecology and Stock Enhancement of Swimming Crab Portunus trituberculatus in Osaka Bay. Bulletin of the Osaka Prefectural Fisheries Experimental Station 12, 1 - 90.

Barshaw, D.E and Lavalli, K.L. (1988) Predation upon postlarval lobsters, Homarus americanus, by cunners, Tauogolabrus adspersus, and mud crabs, Neopanope sayi, on three different substrates: eelgrass, mud, and rocks. Marine Ecology Progress Series 48, 119-123.

Boeger, W.A., Pie, M.R., Ostrensky, A. and Patella, L. (2005) Lethargic crab disease: multidisciplinary evidence supports a mycotic etiology. Memórias do Instituto Oswaldo Cruz 100, 161-167.

Branco, J.O. (1993) Aspectos bioecológicos do caranguejo Ucides cordatus (Linnaeus, 1763)(Crustacea, Decapoda) do manguezal de Itacorubi, Santa Catarina, Br. Arquivos de Biologia e Tecnologia 36, 133-148. 
Chan, B.K.K., Chan, K.K.Y. and Leung, P.C.M. (2006) Burrow architecture of the ghost crab Ocypode ceratophthalma on a sandy shore in Hong Kong. Hydrobiologia 560, 43-49.

Diegues, A.C. (1987) Conservação e desenvolvimento sustentado de ecossistemas litorâneos no Brasil. In- $1^{\circ}$ Simpósio sobre ecossistemas da costa do sul e Sudeste brasileira. Academia de ciências de São Paulo. São Paulo, Brazil. pp. 196-243.

Diele, K. (2000) Life history and population structure of the exploited mangrove crab $U$. cordatus (L.) (Decapoda: Brachyura) in the Caeté estuary, North Brazil. Doctor's thesis. Zentrum für Marine Tropenökologie, Universität Bremen, Bremen, Germany. 103 p.

Dittel, A., Epifanio, C.E. and Natunewicz, C. (1996) Predation on mud crab megalopae, Panopeus herbstii H. Milne Edwards: Effect of habitat complexity, predator species and postlarval densities. Journal of Experimental Marine Biology and Ecology 199, 191-202.

Fernandez, M., Armstrong, D. and Iribarne, O. (1993) First cohort of young-of-the-year Dungeness crab, Cancer magister, reduces abundance of subsequent cohorts in intertidal shell habitat. Canadian Journal of Fisheries and Aquatic Sciences 50, 2100-2105.

Gebauer, P., Paschke, K. and Anger, K. (2002) Metamorphosis in a semiterrestrial crab, Sesarma curacaoense: intra and interspecific settlement cues from adult odors. Journal of Experimental Marine Biology and Ecology 268, 1 -12.

Gebauer, P., Walter, I. and Anger, K. (1998) Effects of substratum and conspecific adults on the metamorphosis of Chasmagnathus granulata (Dana) (Decapoda: Grapsidae) megalopae. Journal of Experimental Marine Biology and Ecology 223, 185-198.

Harvey, A.W. (1996) Delayed metamorphosis in Florida hermit crabs: multiple cues and constraints (Crustacea: Decapoda: Paguridae and Diogenidae). Marine Ecology Progress Series 141, 27-36.

Heck JR., K.L. and Hambrook, J.A. (1991) Intraspecific interactions and risk of predation for Dyspanopeus sayi (Decapoda: Xanthidae) living on polychaete (Filograna implexa Serpulidae) colonies. Marine Ecology Progress Series 12, 243250.

Hemmi, J.M. (2005) Predator avoidance in fiddler crabs: Escape decisions in relation to the risk of predation. Animal Behavioral 69, 603-614.

Islam, S., Machiko, K. and Shigemitsu, S. (2005) Larval development of the swimming crab Thalamita pelsarti Montgomery, 1931 (Crustacea: Brachyura: Portunidae) reared in the laboratory. Russian Journal of Marine Biology 31, 78-90.

Jamieson, G.S. and Phillips, A. (1993) Megalopal spatial distribution and stock separation in
Dungeness crab (Cancer magister). Canadian Journal of Fisheries and Aquatic Sciences 50, 416-429.

Johns, P. and Mann, K.H. (1987) An experimental investigation of juvenile lobster habitat preference and mortality among habitats of varying structural complexity. Journal of Experimental Marine Biology and Ecology 109, 275-85.

McMillan, R.O., Armstrong, D.A. and Dinnel, P.A. (1995) Comparison of intertidal habitat use and growth rates of two northern Puget Sound cohorts of 0+ age Dungeness crab, Cancer magister. Estuaries 18, 390398.

Moksnes, P.O., Lipcius, R.N., Pihl, L. and J. Van Montfrans (1997) Cannibal-prey dynamics in juveniles and postlarvae of the blue crab. Journal of Experimental Marine Biology and Ecology 215, 157-187.

Moksnes, P.O., Pihl, L. and Van Montfrans, J. (1998) Predation on postlarvae and juveniles of the shore crab Carcinus maenas: Importance of shelter, size and cannibalism. Marine Ecology Progress Series 166, 211225.

O'Connor, N. and Judge, M.L. (1997) Flexibility in timing of molting of fiddler crab megalopae: evidence from in situ manipulation of cues. Marine Ecology Progress Series 146, 55-60.

Olmi, E.J. and Lipcius, R.N. (1991) Predation on postlarvae of the blue crab Callinectes sapidus Rathbun by sand shrimp Crangon septemspinosa Say and grass shrimp Palaemonetes pugio Holthius. Journal of Experimental Marine Biology and Ecology 151, 169183.

Quinitio, E. T. and Parada-Estepa, F.D. (2000) Transport of Scylla serrata megalopae at various densities and durations. Aquaculture 185, 63-71.

Rodrigues, M.D. and Hebling, N.J. (1989). Ucides cordatus cordatus (Linnaeus, 1763) (Crustacea, Decapoda). Complete larval development under laboratory conditions and its systematic position. Revista Brasileira de Zoologia 6, 147-166.

Rodríguez, R.A and Epifanio, C.E. (2000) Multiple cues for induction of metamorphosis in larvae of the common mud crab Panopeus herbstii. Marine Ecology Progress Series 195, 221-229.

Santarosa-Freire, A. (1998) Dispersão larval do caranguejo do mangue Ucides cordatus (L.1763) em manguezais da Baía de Paranaguá, Paraná. Doctor's thesis. Universidade de São Paulo, São Paulo, Brazil. $71 \mathrm{p}$.

Secor, D. H., Hines, A. H. and Place, A.R. (2002) Japanese Hatchery-based Stock Enhancement: Lessons for the Chesapeake Bay Blue Crab. Maryland. Sea Grant Publication Number UM-SG-TS-2002-02. Maryland.

Tsukamoto, K., Kuwada, H., Uchida, K., Masuda, R. and Sakakura, Y. (1999) Fish quality and stocking effectiveness: Behavioral approach. In-Stock enhancement and sea ranching. Oxford. Fishing new books, Oxford, USA . pp. 205-218 
Wolff, M., Koch, V. and Isaac, V. (2000) A trophic flow model of the Caeté mangrove estuary, North Brazil, with considerations of the sustainable use of its resources. Estuarine Coastal and Shelf Science 50, 789-8.
Zeil, J. and Hemmi, J.M. (2006) The visual ecology of fiddler crabs. Journal of Comparative Physiology 192, $1-25$.

Received: December 21, 2006; Revised: August 20, 2007; Accepted: May 23, 2008. 